\title{
Optimization of Drainage Schemes for the Dike Strengthening by Warping Construction Project in the Qinhe River under Restricted Drainage Condition
}

\author{
Hao-Ming Yang ${ }^{1}$, Min Zhang $^{1}$ and Cheng-Hui Dong ${ }^{1 *}$ \\ ${ }^{1}$ Yellow River Institute of Hydraulic Research, 450003 Zhengzhou, China
}

\begin{abstract}
Dike strengthening by warping construction is one of the main construction modes for the standardized dike construction of mainstream and tributaries in the lower reaches of the Yellow River, and whether the drainage in the dike strengthening by warping construction is smooth is closely related to the safety of dike project. Restricted by topographic conditions and construction conditions, existing drainage schemes are not applicable to the Qinhe River (the Yellow River's largest tributary) Flood Prevention Project Wuzhi Section, which is next to farm cottage. Therefore, in this paper a field test was carried out using three drainage schemes---"L" type PVC seepage drainage pipes through dike, "L" type perforated PVC seepage drainage pipes coated with geotextile and geotextile drainage grilles. The drainage velocity, silt retaining effect, water level in the silt area, dike body deformation and other key indicators were obtained through field monitoring, and the safety and stability of the dike strengthening by warping construction project were verified by numerical calculation. The field test results showed that the drainage effect of the "L" type perforated PVC seepage drainage pipes coated with geotextile and geotextile drainage grilles was obviously better than that of the "L" type PVC seepage drainage pipes through dike, but the geotextile drainage grilles had advantages in silt retaining effect, construction convenience, cost, and improvement. The field test results can provide a reference for the quick drainage design and construction of dike back deposited with silt of the dike strengthening by warping construction project in the Yellow River.
\end{abstract}

\section{Introduction}

In recent years, standardized dike construction of mainstream and tributaries in the middle and lower reaches of the Yellow River is carried out in China, among which dike strengthening by warping construction is one of the main construction modes. The dike strengthening by warping construction is the process where the deposited silt in the channels of the Yellow River is diverted and placed in the back side of the Yellow River. In the dike strengthening by warping construction of mainstream and tributaries in the middle and lower reaches of the Yellow River in Henan and Shandong, cracks mostly occur in the dike on the reverse river side. The main reasons are that the poor drainage or lag of dike back deposited with silt cause long-time immersion of the dike, and the loading of silt earthwork cause subsidence of the surface on the reverse river side $^{[1-2]}$. Therefore, the drainage is one of the key steps of strengthening by warping construction. At present, the drainage scheme of plastic sheet overflow or laying drainage pipe is mainly adopted for the dike strengthening by warping construction of the Yellow River, achieving poor drainage effects ${ }^{[3]}$. Some scholars conducted a drainage test using gravel blind ditches, earthwork pads and horizontal-vertical complex PVC permeation pipes and confluence pulp collector composite systems in Dongming County and Heze County in Shandong Province as well as other places, achieving good drainage effects ${ }^{[4-5]}$; the design of drainage system is also very important in similar projects such as mine project and hydraulic fill project. For example, the drainage roadways, sand-wells, cut-off ditches and other drainage methods are mainly adopted in the underground drainage of mine project ${ }^{[6-8]}$; the methods for hydraulic fill project, such as plastic drainage plate, pressure consolidation and vacuum preloading drainage are widely adopted in the hydraulic fill project of foundation ${ }^{[9-11]}$. However, the Qinhe River (the Yellow River's largest tributary) Flood Prevention Project Wuzhi Section is next to farm cottage, so it does not have the condition of draining directly to the surrounding areas, and also can not directly use the above drainage systems and methods. To solve the above problem, in this paper a field test was carried out using three drainage schemes in the Qinhe River Flood Prevention Project Wuzhi Section.

\section{Drainage schemes}

${ }^{a}$ Corresponding author: 
The Qinhe River Flood Prevention Project Wuzhi Section was constructed by unit, and the dimension of construction unit was $120 \mathrm{~m} \times 100 \mathrm{~m}$. As it does not have the condition of draining directly to the surrounding areas, in the drainage scheme designed 6-8 adjacent construction units were classified as a group. In the process of warping, the accumulated water was drained to the construction unit in the most tail end by using drainage facilities, and pumped to the grout making pool for recycle. A field test was carried out using three drainage schemes-"L" type PVC seepage drainage pipes through dike, "L" type perforated PVC seepage drainage pipes coated with geotextile and geotextile drainage grilles according to the construction conditions of the Qinhe River Flood Prevention Project Wuzhi Section based on the principle of convenient construction and low cost. The specific methods are as follows.

(1) "L" type PVC seepage drainage pipes through dike

The "L" type PVC seepage drainage pipes through screen dike set up under the dike between two construction units, with a pipe diameter of $25 \mathrm{~cm}$, transverse length of $500 \mathrm{~cm}$, and initial height of $50 \mathrm{~cm}$. The height increased $30 \mathrm{~cm}$ with every increase of siltation height in the test area to ensure that the water was clear after precipitation through the "L" type PVC seepage drainage pipes through dike.

(2) "L" type perforated PVC seepage drainage pipes coated with geotextile

The "L" type PVC seepage drainage pipes through dike were drilled for improvement. The perforation opening ratio was $15 \%$, and the perforation size was $\Phi 10 \mathrm{~mm}$; the thickness of geotextile was $1.5 \mathrm{~mm}$, the mass of unit area was $125 \mathrm{~g} / \mathrm{mm} 2$, and the coefficient of permeability was $1.1 \times 10-1 \mathrm{~cm} / \mathrm{s}$.

(3) Geotextile drainage grilles

The frame of geotextile drainage grilles with a dimension of $125 \mathrm{~cm} \times 100 \mathrm{~cm}$ was made up of PVC materials. A layer of geotextiles were filled inside the frame, and the two sides of the frame were clamped by steel wire mesh. The characteristic parameters of geotextiles were consistent with those in the drainage scheme 2. The schematic diagrams of the three drainage schemes are shown in Figs. 1 and 2.

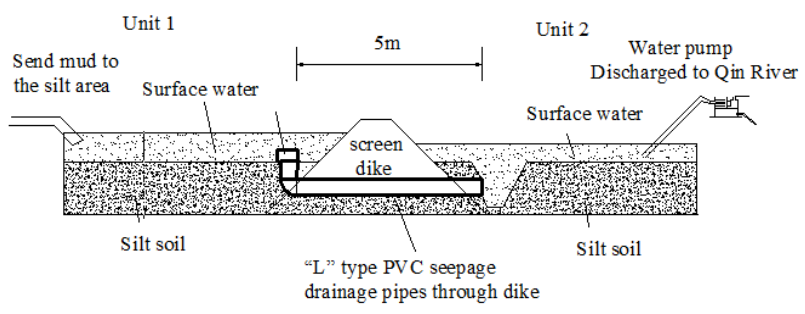

Fig. 1 Schematic diagram of "L" type PVC seepage drainage pipes through dike

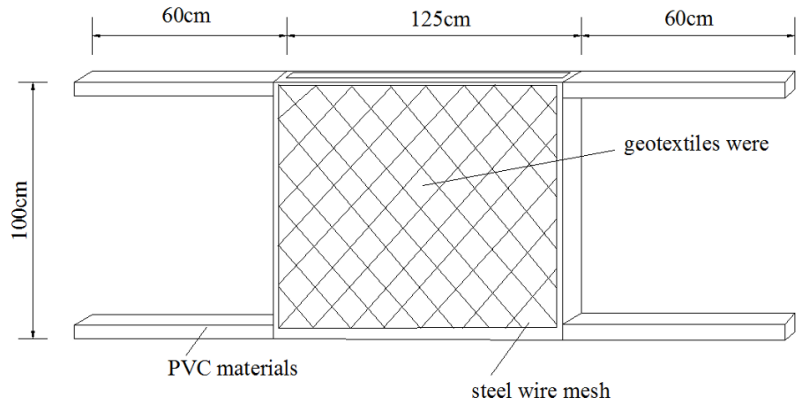

Fig. 2 Schematic diagram of geotextile drainage grilles

The Qinhe River dike stake No. 72+370 73+090 sections were selected as the test areas, including a total of 6 construction units. To ensure the contrast effect of the test, 2 continuous construction units of the same size were selected for test for each drainage scheme. 6 construction units were divided into 3 test areas and 6 test units, which were numbered separately.

To compare the drainage effects of the three drainage schemes, two kinds of field tests were conducted: (1) Field test of drainage velocity and drainage silt content; (2)Field monitoring of groundwater level and dike body deformation. There were 2 water level monitoring points in each test area, a total of 6 water level monitoring points, all of which were located in the middle of the silt area; there were 2 deformation monitoring points in each test area, a total of 6 deformation monitoring points, which were located in the dike slope and dike top respectively. The laying heights of all the sensors were the same; the laying of drainage facilities and the distribution of monitoring points are shown in Fig. 3.

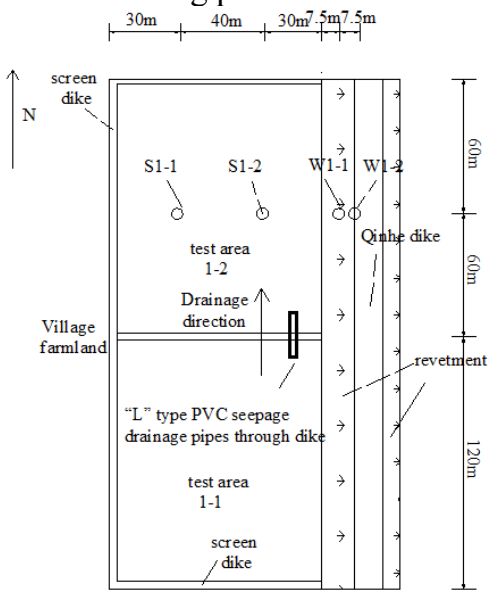

(a) Laying diagram of drainage scheme 1 


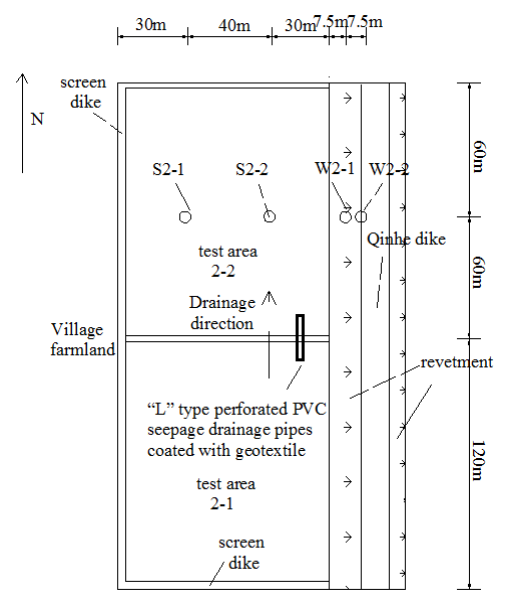

(b) Laying diagram of drainage scheme 2

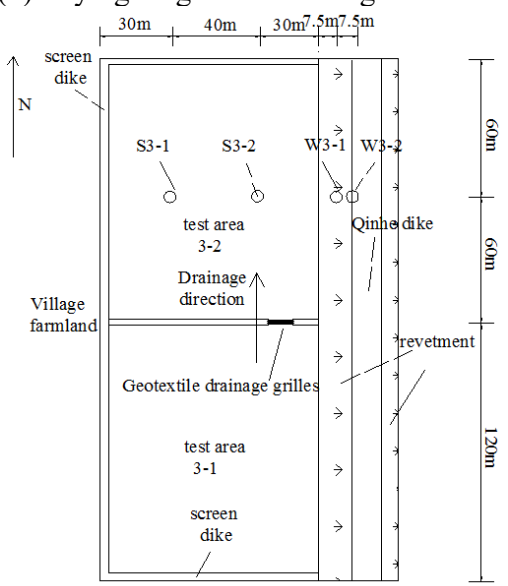

(c) Laying diagram of drainage scheme 3

Fig. 3 Schematic diagram of the drainage schemes and distribution of water level monitoring points

\section{Field test process and observation data analysis}

\subsection{Review of test}

The warping was started on June 19, 2014, and the initial silt height in each test area was about $97.22 \mathrm{~m} \sim 97.41 \mathrm{~m}$, and the initial water level in the test area was low, and the accumulated water was drained by plastic sheet overflow. To July 9, 2014, the silt height in the test area increased to about $99.40 \mathrm{~m}$, at which time the field test was conducted, and ended on July 16, 2014.

\subsection{Analysis of the field test results of drainage silt content and drainage velocity}

The purpose of dike strengthening by warping construction was that the soil particles in the silt reinforced the dike on the reverse river side when deposited, and the drainage silt content and drainage velocity in the drainage process were two indicators for the evaluation of quality of the drainage schemes. During the test, from 8 a.m. to 8 p.m. the silt at the drainage inlet and drainage outlet was collected every one hour, and the drainage velocity was measured at the same time. The detailed results are shown in Tables 1 and 2.

Based on the test data: (1) From Table 1 we can see that in the drainage scheme 1 and drainage scheme 2, there was little difference between the drainage silt content at the drainage outlet and the drainage silt content before being treated with drainage facilities during the test, in contrast, in the drainage scheme 3 the drainage silt content decreased significantly through filtering with geotextile drainage grilles, and the percentage of soil particles between $0.075 \mathrm{~mm}-0.005$ $\mathrm{mm}$ decreased significantly, which were conducive to the progress of dike strengthening by warping construction. (2) From Table 2 we can see that the drainage scheme 3 >drainage scheme 2 >drainage scheme 1 in drainage velocity.

Table 1 Variation of drainage silt content

\begin{tabular}{|c|c|c|c|c|}
\hline \multicolumn{2}{|c|}{ Drainage schemes } & $\begin{array}{l}\text { Drainage } \\
\text { scheme 1 }\end{array}$ & $\begin{array}{c}\text { Drainage scheme } \\
2 \\
\end{array}$ & $\begin{array}{l}\text { Drainage } \\
\text { scheme } 3 \\
\end{array}$ \\
\hline \multirow{2}{*}{$\begin{array}{c}\text { Drainage silt } \\
\text { content } \\
\left(\mathrm{kg} / \mathrm{m}^{3}\right)\end{array}$} & $\begin{array}{c}\text { Before } \\
\text { drainage }\end{array}$ & \multicolumn{3}{|c|}{$80 \sim 115$} \\
\hline & $\begin{array}{c}\text { After } \\
\text { drainage }\end{array}$ & $78 \sim 112$ & $75 \sim 111$ & $44 \sim 56$ \\
\hline \multirow{2}{*}{$\begin{array}{l}\text { Particle size } \\
\text { gradation } \\
\quad(\%)\end{array}$} & $\begin{array}{l}\text { Before } \\
\text { drainage }\end{array}$ & \multicolumn{2}{|c|}{$\begin{array}{l}\text { (1) } 0.25-0.075 \mathrm{~mm}: 1 \sim 4 \\
\text { (2) } 0.075-0.005 \mathrm{~mm}: 61 \sim 65 \\
\text { (3) }<0.005 \mathrm{~mm}: 32 \sim 35 \\
\end{array}$} & \\
\hline & $\begin{array}{c}\text { After } \\
\text { drainage }\end{array}$ & $\begin{array}{l}\text { No significant } \\
\text { change }\end{array}$ & $\begin{array}{l}\text { (1) } 1 \sim 3 \\
\text { (2) } 61 \sim 65 \\
\text { (3) } 37 \sim 40\end{array}$ & $\begin{array}{l}\text { (1) } 0 \\
\text { (2) } 11 \sim 17 \\
\text { (3) } 83 \sim 89\end{array}$ \\
\hline
\end{tabular}

Table 2 Test results of drainage velocity

\begin{tabular}{cccc}
\hline Drainage schemes & $\begin{array}{c}\text { Drainage } \\
\text { scheme 1 }\end{array}$ & $\begin{array}{c}\text { Drainage } \\
\text { scheme 2 }\end{array}$ & $\begin{array}{c}\text { Drainag } \\
\text { e scheme } \\
\mathbf{3}\end{array}$ \\
\hline $\begin{array}{c}\text { Drainage velocity } \\
\text { range }(\mathrm{cm} / \mathrm{s})\end{array}$ & $29.3 \sim 47.5$ & $43.7 \sim 57$ & $6.1 \sim 7.5$ \\
\hline $\begin{array}{c}\text { Average drainage } \\
\text { velocity }(\mathrm{cm} / \mathrm{s})\end{array}$ & 33.8 & 48.5 & 6.9 \\
\hline Drainage area $\left(\mathrm{m}^{2}\right)$ & 0.049 & 0.049 & 0.38 \\
\hline $\begin{array}{c}\text { Average daily drainage } \\
\text { capacity }\left(\mathrm{m}^{3} / \mathrm{d}\right)\end{array}$ & 1642.64 & 2053.30 & 2146.18 \\
\hline
\end{tabular}

\subsection{Analysis of monitoring results}

(1) Analysis of water level monitoring results

The water level of monitoring points was obtained through the 6 water level gauges laid in the test areas 12 3-2. Fig. 4 shows the variation of water level of the 6 water level monitoring points in the test area, and the water level increment at each water level monitoring point is shown in Table 3. From Fig. 4 and Table 3 we can see that under the condition of the same warping amount, the rising of water level of the water level monitoring points S1-1 and S1-2 in the test area in the drainage scheme 1 was significantly higher than that in the drainage scheme 2 and drainage scheme 3 . There was little difference between the rising of water level of the water level monitoring points S1-1 and S1-2 in the test area in the drainage scheme 2 and drainage scheme 3, which was consistent with the field test results of drainage velocity. 


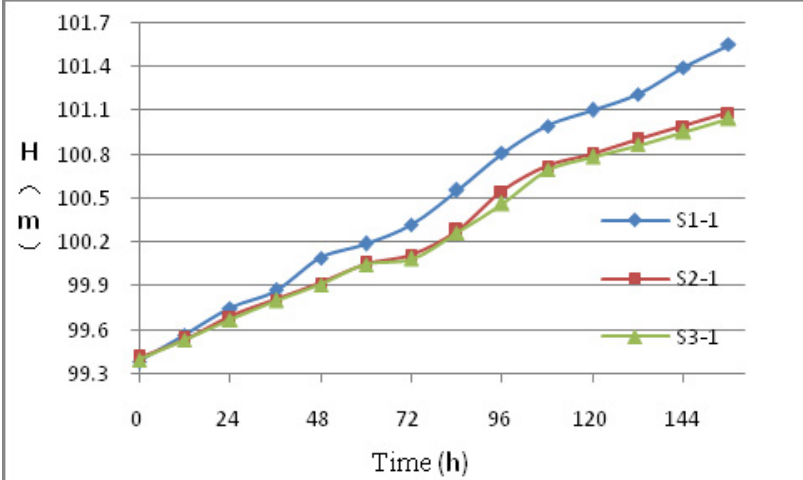

(a)

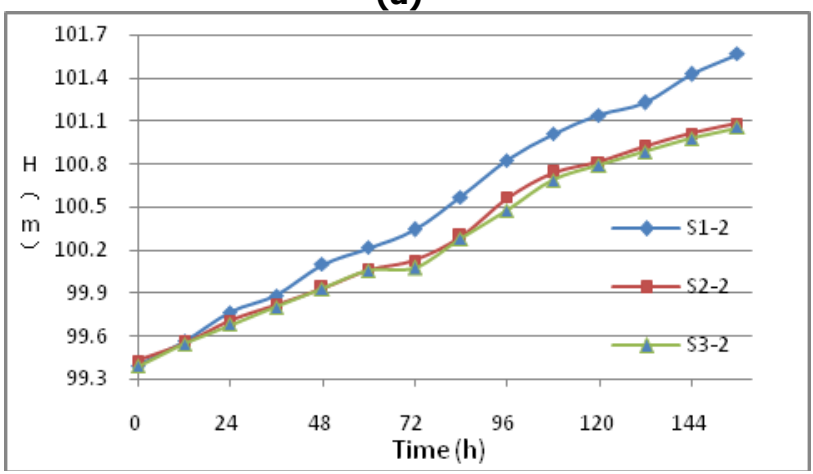

(b)

Fig.4 Variation of water level in the test area

Table 5 Comparison of water level at each water level monitoring point

\begin{tabular}{|c|c|c|c|c|}
\hline \multirow{2}{*}{$\begin{array}{l}\text { Number of } \\
\text { water level } \\
\text { monitori- } \\
\text { ng points }\end{array}$} & \multicolumn{2}{|c|}{$\begin{array}{c}\text { Water level of water } \\
\text { level monitoring } \\
\text { points(m) }\end{array}$} & \multirow{2}{*}{$\begin{array}{l}\text { Water level } \\
\text { increment } \\
(\mathrm{m})\end{array}$} & \multirow{2}{*}{$\begin{array}{l}\text { Daily water } \\
\text { level } \\
\text { increment } \\
\text { (m) }\end{array}$} \\
\hline & $\begin{array}{l}\text { Before } \\
\text { the test }\end{array}$ & $\begin{array}{l}\text { After the } \\
\text { test }\end{array}$ & & \\
\hline S1-1 & 99.385 & 101.553 & 2.168 & 0.310 \\
\hline S1-2 & 99.388 & 101.566 & 2.178 & 0.311 \\
\hline S2-1 & 99.41 & 101.085 & 1.675 & 0.239 \\
\hline S2-2 & 99.423 & 101.078 & 1.655 & 0.236 \\
\hline S3-1 & 99.396 & 101.046 & 1.650 & 0.236 \\
\hline S3-2 & 99.387 & 101.052 & 1.665 & 0.238 \\
\hline
\end{tabular}

(2) Analysis of dike body deformation monitoring results

The observed objects for dike body deformation included horizontal displacement (X direction--perpendicular to the dike body, the area facing the area deposited with silt was "+", and the area with back to the area deposited with silt was "-"; Y direction--parallel to the dike body, the area facing the area deposited with silt towards the right was "+", and the area facing the area deposited with silt towards the left was "-") and vertical displacement of the dike body $(Z$ direction was the vertical displacement of the dike body, the uplift was "+", and the subsidence was "“-”.). The monitoring results of the dike body deformation in each direction are shown in Fig. 5. (Note: the numerical values were cumulative deformation data after construction started on June 19th, Fig. 5 shows only the deformation data during the test).
From Fig. 5 we can see that during the drainage test, the deformation mainly occurred in the dike slope, and the directions of displacement were mainly $\mathrm{X}$ and $\mathrm{Z}$ directions. During the test, the deformation in the drainage scheme 1 was slightly large, and there was little difference between the deformation in the drainage scheme 2 and drainage scheme 3 .

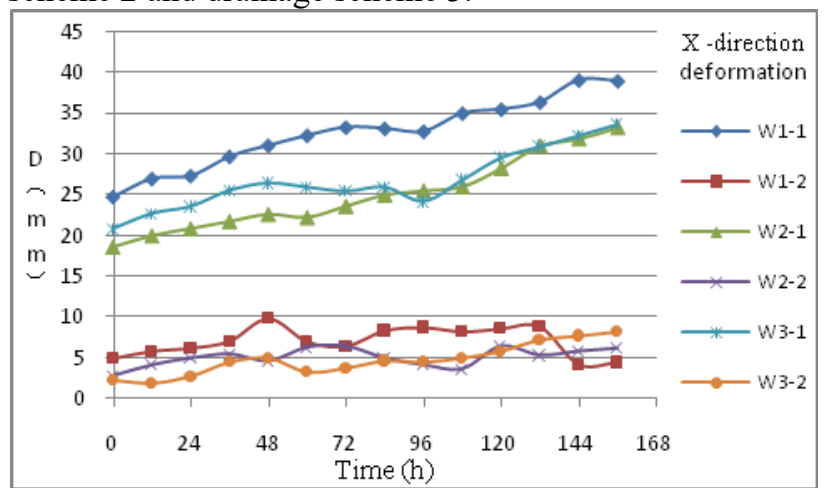

(a) X-direction deformation at dike body monitoring points

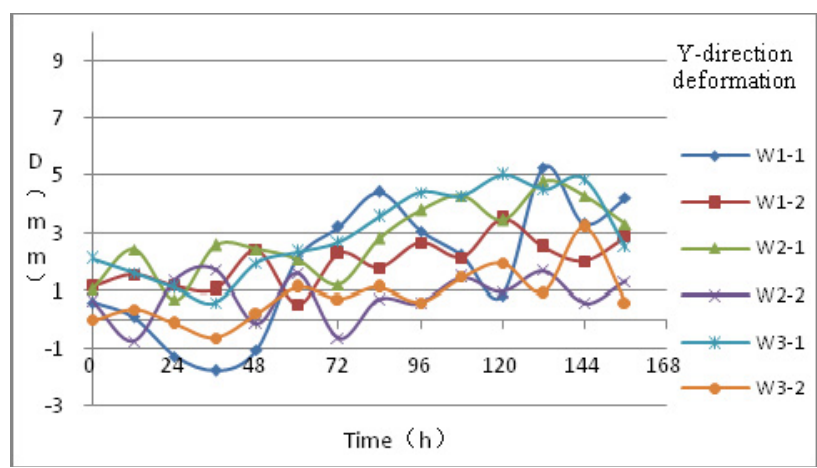

(b) Y-direction deformation at dike body monitoring points

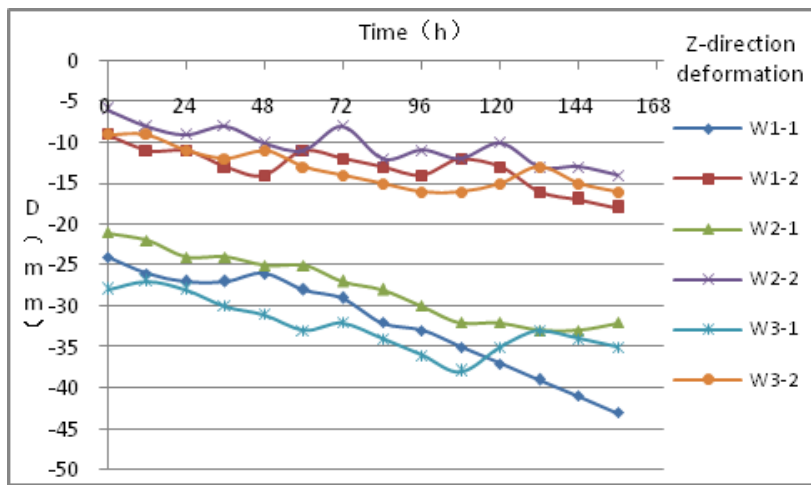

(c) $\mathrm{Z}$ direction deformation at dike body monitoring point

Fig.5 Monitoring results of dike body deformation in the test area 


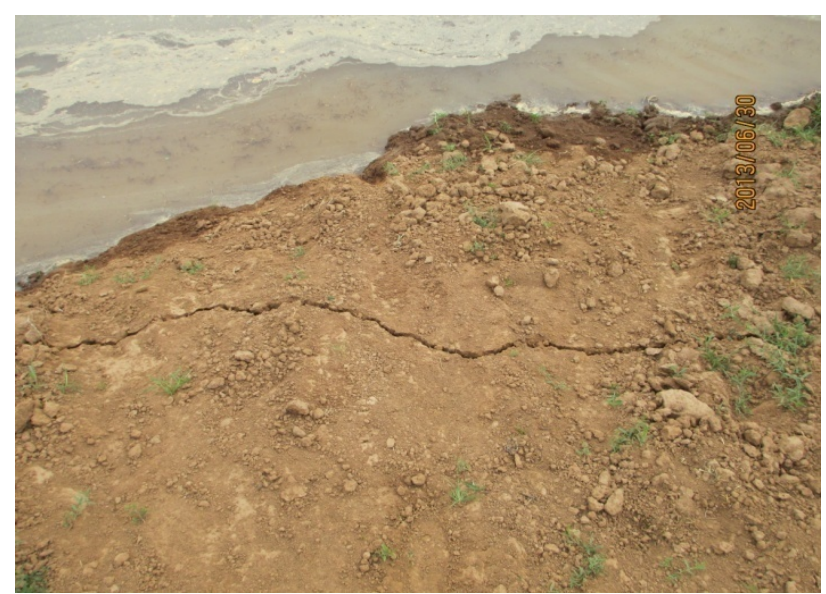

Fig. 6 Crack in the dike

\section{Numerical calculation and simulation}

Taking the test area $72+900$ as the calculation section, on the basis of indoor soil test parameters, the overall stability of the dike body before and after the warping was analyzed using Geo-studio software; in the process of warping where the water level constantly changed, the permeability of the dike body was analyzed, then the effect of the dike strengthening by warping construction on the saturation line and dike body stability was analyzed. The calculation parameters are shown in Table 3 , and the calculation model is shown in Fig. 7.

Table 3 Parameters for numerical calculation

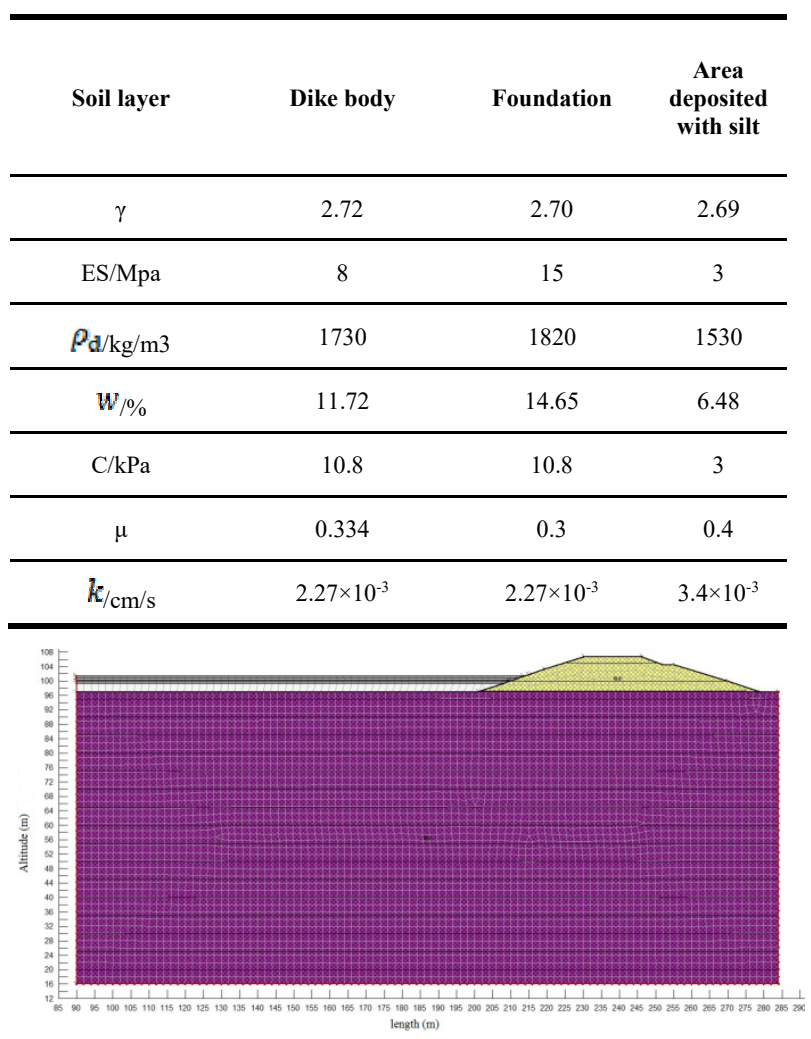

Fig.7 Calculation model of stability

After the dike strengthening by warping construction, the stability of the dike body was greatly improved. The results are shown in Table 4.
Table 4 Summary of dike toe deformation

\begin{tabular}{ccccc}
\hline $\begin{array}{c}\text { Calculation } \\
\text { methods }\end{array}$ & Janbu & Ordinary & Bishop & M-P \\
\hline $\begin{array}{c}\text { Before the } \\
\text { construction }\end{array}$ & 1.913 & 1.931 & 1.975 & 1.974 \\
\hline $\begin{array}{c}\text { After the } \\
\text { construction }\end{array}$ & 2.275 & 2.338 & 2.494 & 2.490 \\
\hline
\end{tabular}

According to the field test conditions, the deformation of the dike body in all stages was calculated. The results are shown in Table 5.The calculated results were consistent with the overall trend of field monitoring results.

Table 5 Summary of dike toe deformation

\begin{tabular}{cccc}
\hline Time period & $\begin{array}{c}\text { Drainage } \\
\text { scheme 1 }\end{array}$ & $\begin{array}{c}\text { Drainage } \\
\text { cheme 2 }\end{array}$ & $\begin{array}{c}\text { Drainage } \\
\text { scheme 3 }\end{array}$ \\
\hline $\begin{array}{c}\text { Horizontal } \\
\text { deformation } \\
(\mathrm{mm})\end{array}$ & 28 & 24 & 25 \\
\hline $\begin{array}{c}\text { Vertical } \\
\text { deformation } \\
(\mathrm{mm})\end{array}$ & -33 & -25 & -26 \\
\hline
\end{tabular}

\section{Optimization of drainage schemes}

The Qinhe River Flood Prevention Project Wuzhi Section has difficulty in draining as it does not have the condition of draining directly to the surrounding areas. To solve the above problem, in this paper a field test was carried out using three drainage schemes in the Qinhe River Flood Prevention Project Wuzhi Section. The advantages and disadvantages of the three drainage schemes were analyzed and summarized through field test, filed monitoring and numerical calculation combined with the specific circumstances of the construction site, as shown in Table 6 . From Table 6 we can see that there was little difference between the field test, numerical calculation and other indicators in the drainage scheme 2 and drainage scheme 3 , but the drainage scheme 3 had advantages in silt retaining effect, construction convenience, cost, and improvement. Thus, the drainage scheme 3 (geotextile drainage grille) was the best drainage scheme of the three drainage schemes.

Table 6 Analysis of advantages and disadvantages of the three drainage schemes

\begin{tabular}{|c|c|c|c|c|}
\hline \multicolumn{2}{|c|}{ Drainage schemes } & $\begin{array}{c}\text { Drainage scheme } \\
1\end{array}$ & $\begin{array}{c}\text { Drainage scheme } \\
2\end{array}$ & $\begin{array}{l}\text { Drainage } \\
\text { scheme } 3\end{array}$ \\
\hline \multirow{4}{*}{$\begin{array}{l}\text { Analysi } \\
\text { s of } \\
\text { field } \\
\text { test } \\
\text { results }\end{array}$} & $\begin{array}{l}\text { Drainage } \\
\text { velocity }\end{array}$ & Slowest & Fastest & $\begin{array}{c}\text { Slightly } \\
\text { slower than } \\
\text { the drainage } \\
\text { scheme 2 }\end{array}$ \\
\hline & $\begin{array}{l}\text { Silt retaining } \\
\text { effect }\end{array}$ & $\begin{array}{l}\text { No silt retaining } \\
\text { capability }\end{array}$ & $\begin{array}{l}\text { Weak silt } \\
\text { retaining } \\
\text { capability }\end{array}$ & $\begin{array}{c}\text { Strong silt } \\
\text { retaining } \\
\text { capability }\end{array}$ \\
\hline & $\begin{array}{l}\text { Variation of } \\
\text { water level }\end{array}$ & $\begin{array}{c}\text { Most water level } \\
\text { increment }\end{array}$ & \multicolumn{2}{|c|}{$\begin{array}{l}\text { Little difference between the drainage } \\
\text { scheme } 2 \text { and drainage scheme } 3\end{array}$} \\
\hline & $\begin{array}{c}\text { Deformation } \\
\text { monitoring }\end{array}$ & $\begin{array}{c}\text { Largest } \\
\text { deformation }\end{array}$ & Small deformation & $\begin{array}{c}\text { Small } \\
\text { deformation }\end{array}$ \\
\hline
\end{tabular}




\begin{tabular}{|c|c|c|c|c|}
\hline \multirow{4}{*}{$\begin{array}{l}\text { Analysi } \\
\mathrm{s} \text { of on- } \\
\text { site } \\
\text { construc } \\
\text { tion }\end{array}$} & $\begin{array}{l}\text { Cost } \\
\text { (ten } \\
\text { thousand } \\
\text { Yuan) }\end{array}$ & 0.31 & 0.33 & 0.12 \\
\hline & $\begin{array}{l}\text { Construction } \\
\text { convenience }\end{array}$ & $\begin{array}{l}\text { Large machinery } \\
\text { for construction } \\
\text { was required }\end{array}$ & $\begin{array}{l}\text { Large machinery } \\
\text { for construction } \\
\text { was required }\end{array}$ & $\begin{array}{c}\text { Large } \\
\text { machinery for } \\
\text { construction } \\
\text { was not } \\
\text { required } \\
\end{array}$ \\
\hline & Improvement & $\begin{array}{l}\text { With the gradual } \\
\text { increase of water } \\
\text { level,the distance } \\
\text { between the } \\
\text { drainage outlet } \\
\text { and the dike } \\
\text { became farther } \\
\text { after the drainage } \\
\text { outlet was } \\
\text { gradually } \\
\text { heightened, } \\
\text { which was not } \\
\text { conducive to the } \\
\text { construction and } \\
\text { there was small } \\
\text { room for } \\
\text { improvement }\end{array}$ & $\begin{array}{l}\text { The same as the } \\
\text { drainage scheme } 1\end{array}$ & $\begin{array}{l}\text { Can increase } \\
\text { the drainage } \\
\text { area of } \\
\text { geotextile } \\
\text { drainage } \\
\text { grilles; two } \\
\text { geotextile } \\
\text { drainage } \\
\text { grilles were } \\
\text { formed on the } \\
\text { dike for } \\
\text { alternative use }\end{array}$ \\
\hline & $\begin{array}{l}\text { Environment } \\
\text { al protection }\end{array}$ & $\begin{array}{l}\text { After the } \\
\text { construction, the } \\
\text { PVC seepage } \\
\text { drainage pipes } \\
\text { deposited in the } \\
\text { area deposited } \\
\text { with silt, causing } \\
\text { pollution to a } \\
\text { certain extent }\end{array}$ & $\begin{array}{l}\text { The same as the } \\
\text { drainage scheme } 1\end{array}$ & $\begin{array}{l}\text { The geotextile } \\
\text { drainage } \\
\text { grilles can be } \\
\text { recycled, no } \\
\text { pollution; the } \\
\text { accumulated } \\
\text { water in the } \\
\text { area deposited } \\
\text { with silt was } \\
\text { pumped to the } \\
\text { silt dredging } \\
\text { area for } \\
\text { recycle }\end{array}$ \\
\hline \multicolumn{2}{|c|}{$\begin{array}{l}\text { Numerical calculation } \\
\text { results }\end{array}$} & $\begin{array}{c}\text { Largest } \\
\text { deformation }\end{array}$ & Small deformation & $\begin{array}{c}\text { Small } \\
\text { deformation }\end{array}$ \\
\hline
\end{tabular}

\section{Conclusion and suggestion}

The Qinhe River Flood Prevention Project Wuzhi Section has difficulty in draining as it does not have the condition of draining directly to the surrounding areas. To solve the above problem, in this paper a field test was carried out using three drainage schemes in the Qinhe River Flood Prevention Project Wuzhi Section with the Qinhe River dike stake No. 72+370 73+090 sections as the test areas. The effect of the three drainage schemes on the dike strengthening by warping construction under restricted drainage condition was analyzed through field test, theoretical analysis and numerical simulation of dike body stability under the change of water level. The main conclusions were as follows:

(1) According to the characteristics of the dike strengthening construction project of the Qinhe River in Jiaozuo, a field test was carried out using three drainage schemes---"L" type PVC seepage drainage pipes through dike (drainage scheme 1), "L" type perforated PVC seepage drainage pipes coated with geotextile (drainage scheme 2) and geotextile drainage grilles (drainage scheme 3). Also, the field tests (drainage velocity test, field monitoring, drainage test) were carried out. The field test results showed that the drainage effect of the drainage scheme 2 and drainage scheme 3 was good, and the drainage effect of the drainage scheme 1 was poor.

(2) The deformation and dike body stability before and after the dike strengthening by warping construction were analyzed. With the increase of the water level in the silt area, the stability coefficient decreased, thus the drainage scheme was considered to be reasonable. The water level in the silt area was low, which did not affect the overall stability of the dike body; during the drainage test, the dike body deformation in the drainage scheme 2 and drainage scheme 3 was small.

(3) By considering and comparing the test data, monitoring results, economic benefits, construction difficulty, silt retaining effect, energy saving, environmental protection and other factors, the drainage scheme 3 was selected.

\section{Acknowledgements}

The authors acknowledge the financial support from National key R\&D program on monitoring, early warming and prevention of major natural disasters (2017YFC1501202); Basic research business expenses special funds of Central level and public welfare research institutes(Nos. HKY-JBYW-2018-14).

\section{References}

1. Shen Xi-zhong, Feng Xia-ting. Numerical analysis of endanger of crack in standardization of Yellow River in Dongming of Shandong province[J]. Chinese Journal of Rock Mechanics and Engineering, 2009, (Supp 1): 2612-2619.

2. Shen Xi-zhong, Zhang Hui, Yang Wen-li. Causes of longitudinal cracks of standardized dikes for lower Yellow River and their prevention and curing[J]. Rock and Soil Mechanics, 2008, 29(4): 973-978.

3. Du Yu-hai. Study and practice of Dike Strengthening by Warping Construction of the Yellow River [M].Zhengzhou: The Yellow River Water Conservancy Press, 2002.

4. Liu Xiao-wen, Xu Cheng-cheng, Shen Xi-zhong, $\mathrm{Hu}$ Xiao-rong. Experimental study of drainage effect for different drainage measures[J]. Rock of Soil Mechanics[J]. 2010, 31(11): 3563-3568.

5. Zhao An-pin. Theoretical analysis of sediment transport in combined system of confluence and collector [J]. Yellow River, 2009, 12(31): 34-35.

6. Zhou Nian-qing, $\mathrm{Fu} \mathrm{Li}$, Jiang Si-min, et,al. Application of MODLOW to Groundwater Drainage Numberical Simulation in Sanmenxia Bauxite, Journal of TongJi University (Natural Science), 2009,12:1691-1699.

7. Boyacioglu, H. Utilization of the water quality index method as a classification tool[J]. Environment Monitoring and assessment, 2010, 167:115-124.

8. Farshid Abbasi, Alireza Mojtahedi, Mir Mohammad Ettefagh. Faul diagnosis using noise Modeling and a new artificial immune system based algorithm[J]. Earthquake Engineering and Engineering Vibration, 2015,04:725-741.

9. Chen Wei-hua, Liang Yuan-zhong, Zhou Xuan. Experimental research on treating hydraulic fill sand ground with plastic draining plate $[\mathrm{J}]$. Engineering Journal of Wuhan University, 2005, 38(5): 80-82. 
10. Bao Shu-feng, Dong Liang-zhi, Mo Hai-hong, Chen Ping-shan. Field research on dralinage system of vacuum preloading technology for fresh hydraulic reclamation silt[J]. Chinese Journal of Rock Mechanics and Engineering, 2014, 33(2) :4218-4226.

11. Indraratna, B.,Kianfar, K.,Rujikiatkamjorn, C., etc. Soft clay properties for non-Darcian radial drainage with vacuum preloading, based on Rowe cell resting $[\mathrm{J}]$. Australian Geomechanics Journal , 2014 , 49 (4) :183-190 